\title{
Evaluation of Rhododendron Lufeum and Rhododendron Ponticum in Pulp and Paper Production
}

\section{Procjena mogućnosti uporabe biljaka Rhododendron luteum i Rhododendron ponticum kao sirovine za proizvodnju celuloze i papira}

\author{
Original scientific paper • Izvorni znanstveni rad \\ Received-prispjelo: 29. 8. 2019. \\ Accepted-prihvaćeno: 15. 7. 2020. \\ UDK: $630 * 862.2 ; 630 * 862.3$ \\ https://doi.org/10.5552/drvind.2020.1943
}

(C) 2020 by the author(s). Licensee Faculty of Forestry, University of Zagreb. This article is an open access article distributed under the terms and conditions of the Creative Commons Attribution (CC BY 4.0) license.

\begin{abstract}
In this study, Rhododendron luteum and Rhododendron ponticum were evaluated as raw material for pulp and paper production. 12 different sodium borohydride $\left(\mathrm{NaBH}_{4}\right)$ added cooking trials were performed for each sample and kraft method was used for pulp production. Pulp properties, such as yield, kappa number and viscosity, and physical properties, such as breaking length and burst index, were determined for each trial. Besides, the effects of active alkali and $\mathrm{NaBH}_{4}$ on the pulp and paper properties were also examined. Optimum cooking conditions were obtained by using $18 \%$ active alkali for $\mathrm{NaBH}_{4}$-free cooking experiments and $0.5 \% \mathrm{NaBH} 4$ and $18 \%$ active alkali for $\mathrm{NaBH} 4$-added cooking experiments. In $\mathrm{NaBH}_{4}$-added pulping condition, the screened yield, kappa number and viscosity of $\underline{R}$. luteum were found to be $43.4 \%, 40.1$ and $949 \mathrm{~cm}^{3} / \mathrm{g}^{1}$, respectively. The respective values for $\underline{R}$. ponticum were $41.9 \%, 44.5$ and $885 \mathrm{~cm}^{3} / \mathrm{g}^{1}$. The screened yields of $\underline{R}$ luteum and $\underline{R}$. ponticum increased by about $2.8 \%$ and $5.3 \%$, respectively, with $5 \%$ addition of $\mathrm{NaBH}_{4}$ compared to $\mathrm{NaBH}_{4}$-free cooking experiments. Furthermore, with the addition of $\mathrm{NaBH}_{4}$, the kappa numbers decreased while the viscosity increased. The physical properties of the produced papers were also improved by using $\mathrm{NaBH}_{4}$ in cooking liquor. According to the obtained results, it was found that $\underline{R}$. luteum and $\underline{R}$. ponticum species can be evaluated for pulp and paper production.
\end{abstract}

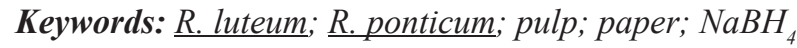

SAŽETAK • U ovom je radu istražena mogućnost uporabe biljaka Rhododendron luteum $i \underline{\text { Rhododendron ponti- }}$ cum kao sirovine za proizvodnju celuloze i papira. Za svaki uzorak provedeno je 12 različitih ispitivanja kuhanja s natrijevim borhidridom (NaBH $)$, a celuloza je proizvedena kraft postupkom. Za svako ispitivanje određena su svojstva celuloze poput prinosa, kappa broja i viskoznosti, te fizička svojstva kao što su duljina lomljenja i indeks pucanja papira. Osim toga, ispitani su učinci aktivne lužine i $\mathrm{NaBH}_{4}$ na svojstva celuloze i papira. Optimalni uvjeti kuhanja postignuti su upotrebom $18 \%$ aktivne lužine za eksperimentalno kuhanje bez $\mathrm{NaBH}_{4}$ i upotrebom 0,5\% $\mathrm{NaBH}_{4}$ i $18 \%$ aktivne lužine za eksperimentalno kuhanje s dodatkom $\mathrm{NaBH}_{4}$. U proizvodnji celuloze iz biljke $\underline{\mathrm{R}}$. luteum $s$ dodatkom $\mathrm{NaBH}_{4}$ utvrđeno je da prinos prosijavanja iznosi 43,4\%, da je kappa broj 40,1, a viskoznost

\footnotetext{
Authors is researcher at Kastamonu University, Araç Rafet Vergili Vocational School, Kastamonu, Turkey.

${ }^{2}$ Author are researchers at KSU Faculty of Forestry, Department of Forest Product Engineering, Kahramanmaraş, Turkey.
} 
$949 \mathrm{~cm}^{3} / \mathrm{g}$, dok su vrijednosti za celulozu dobivenu iz biljke R. ponticum redom 41,9\%, 44,5i $885 \mathrm{~cm}^{3} / \mathrm{g}$. Prinos prosijavanja biljaka $\mathrm{R}$. luteum $i$ R. ponticum uz dodatak $5 \% \mathrm{NaBH}_{4}$ povećao se oko 2,8\% i 5,3\% u usporedbi s eksperimentalnim kuhanjem bez dodatka $\mathrm{NaBH}_{4}$. Nadalje, uz dodatak $\mathrm{NaBH}_{4}$ smanjuju se kappa brojevi, a viskoznosti se povećavaju. Fizička svojstva proizvedenih papira također se poboljšavaju dodavanjem $\mathrm{NaBH}_{4}$ tekućini za kuhanje. Iz dobivenih je rezultata utvrđeno da se biljke $\underline{R}$. luteum $i \underline{R}$. ponticum mogu upotrebljavati u proizvodnji celuloze i papira.

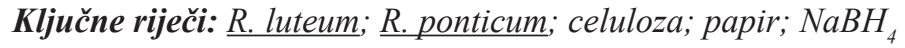

\section{INTRODUCTION 1. UVOD}

In the second half of the twentieth century, especially with the increase of world population and the increase in demand for forest products due to rapid developments in technology, the decrease in forest areas led the forest products industry to search for raw materials as an alternative to wood (Oner and Aslan, 2002; Tutus et al., 2011). Non-wood and new wood products are one of the best alternative raw materials (Kaldor, 1992; Comlekcioglu et al., 2016). Due to the rapid increase in paper consumption in recent years, alternative fibrous materials have gained importance in the pulp and paper industry (Daud and Law, 2011). The search for new wood raw materials still continues in the world.

Rhododendron species, a valuable ornamental shrub, have been cultivated since the $18^{\text {th }}$ century. These species belong to the heath or Ericaceae family. Rhododendron, with about 1000 different species, extends from Southwest Asia to New Guinea. Some Rhododendron species are large species with a tree-type growth habit. It is evergreen or rarely deciduous. Turkish rhododendrons grow naturally up to $3000 \mathrm{~m}$ above the sea level. One of the most remarkable Rhododendron species in moist forest formations covering the northern coast of Turkey is $R$. luteum and the most common Rhododendron is $R$. ponticum. Fiber length, fiber width, lumen diameter and cell wall thicknesses of $R$ luteum and $R$. ponticum are approximately $0.9-1.0$ $\mathrm{mm}, 17-19 \mu \mathrm{m}, 7-9 \mu \mathrm{m}$ and 3-4 $\mu \mathrm{m}$, respectively. Besides, these species have high holocellulose (77-80 \%) and alpha cellulose (47-48 \%) contents, which are important carbohydrates for pulp and paper industry (Birinci, 2008; Camlibel, 2008).

Although they appear on the northern slopes of the mountains on the Black Sea coast, there are more species in the Eastern Black Sea Region (Avci, 2004). In many studies, Rhododendron species have generally been evaluated for the production of medium density fiberboard (MDF) (Akgul et al., 2012; Akgul and Camlibel, 2008; Ayrilmis et al., 2014). Besides, some studies have determined the chemical composition of some Rhododendron species (Birinci, 2008; Shrestha and Budhathoki, 2012).

The kraft method is the most commonly used method for obtaining pulp suitable for papermaking. Increasing the pulp yield in pulp production is very important for the pulp and paper industry in terms of cost and economy. Modifying the kraft cooking process, e.g. by adding $\mathrm{NaBH}_{4}$, is a way of increasing the pulp yield (Courchene, 1998; Tutus and Eroglu, 2003; Tutus and Eroglu, 2004; Tutus and Usta 2004; Hafizoglu and Deniz, 2007; Istek and Gonteki, 2009, Akgul et al., 2018). The end groups of carbohydrates are protected from peeling reactions by using $\mathrm{NaBH}_{4}$ as a catalyst in cooking processes (Istek and Ozkan, 2008; Tutus and Cicekler, 2016).

There is little information about the use of Rhododendron species in wood-based industries and there is no study on their use in pulp and paper production. The aim of this study was to evaluate Rhododendron luteum and Rhododendron ponticum stalks for pulp and paper production, using $\mathrm{Kraft}_{-} \mathrm{NaBH}_{4}$ cooking methods.

\section{MATERIALS AND METHODS 2. MATERIJALI I METODE}

$R$. luteum and $R$. ponticum species were obtained from Akdamar Village of Akçaabat district of Trabzon province in Turkey. The chemical compositions of $R$. luteum and $R$. ponticum were determined in a previous study (Birinci, 2008) and are presented in Table 1 with some wood and non-wood species.

According to Table 1, the chemical composition of Rhododendron species is similar to that of hardwoods species. Rhododendron species show similarities among themselves. However, the lignin content of $R$. ponticum was higher than that of $R$. luteum. Due to their high holocellulose contents, it was concluded that Rhododendron species were considered suitable for pulp and paper production.

The samples were chipped and air dried. 12 cooking trials were applied on each species, using Kraft$\mathrm{NaBH}_{4}$ method given in Table 2 in order to determine optimum pulping conditions.

Cooking trials of the species were applied in a rotary digester with a 15 -liter capacity and high pressure resistant. After cooking processes, the pulps were washed with tap water until the black liquor was removed, and the washed pulps were transferred to 0.15 $\mathrm{mm}$ slotted screen. Screened pulp and screen reject yields were calculated after the screening process. The kappa numbers and viscosity of the screened pulps were determined according to TAPPI T 236 om-13 and TAPPI T 230 om-08, respectively (Anonymous, 1998).

The pulps were beaten to $25 \pm 3{ }^{\circ} \mathrm{SR}$ (Schopper Riegler) freeness level in the hollander beater according to TAPPI T $200 \mathrm{sp}-96$. Ten test papers were produced from the pulps obtained from each cooking trial. The breaking lengths and burst indices of the papers 
Table 1 Chemical composition of $R$. luteum, R. ponticum and some wood and non-wood species

Tablica 1. Kemijski sastav biljaka $R$. luteum, $R$. ponticum i nekih drvnih i nedrvnih vrsta

\begin{tabular}{|l|c|c|c|c|c|c|c|}
\hline $\begin{array}{l}\text { Chemical components } \\
\text { Kemijske sastavnice }\end{array}$ & $\begin{array}{c}\text { R. luteum } \\
\text { (Birinci, } \\
\text { 2008) }\end{array}$ & $\begin{array}{c}\text { R. ponticum } \\
\text { (Birinci, } \\
\text { 2008) }\end{array}$ & $\begin{array}{c}\text { A. mem- } \\
\text { branaceus } \\
\text { (Tutus } \text { et } \\
\text { al., 2014) }\end{array}$ & $\begin{array}{c}\text { Fagus } \\
\text { orientalis } \\
\text { (Tank, } \\
\text { 1978) }\end{array}$ & $\begin{array}{c}\text { R. pseudoa- } \\
\text { cacia } \\
\text { (Kirci, } \\
\text { 1987) }\end{array}$ & $\begin{array}{c}\text { P. brutia } \\
\text { (Tutus } \text { et } \\
\text { al., 2012) }\end{array}$ & $\begin{array}{c}\text { Wheat straw } \\
\text { (Tutus and } \\
\text { Cicekler, } \\
\text { 2016) }\end{array}$ \\
\hline $\begin{array}{l}\text { Holocellulose, \% } \\
\text { holoceluloza, \% }\end{array}$ & 78 & 77 & 77 & 79 & 82 & 79 & 73 \\
\hline $\begin{array}{l}\text { Alpha cellulose, \% } \\
\text { alfa-celuloza, \% }\end{array}$ & 48 & 47 & 50 & 42 & 52 & 49 & 39 \\
\hline Lignin, \% / lignin, \% & 31 & 34 & 24 & 23 & 21 & 28 & 18 \\
\hline Ash, \% / pepeo, \% & 0.41 & 0.42 & 5.50 & 0.61 & 0.55 & 0.48 & 7.8 \\
\hline $\begin{array}{l}\text { Extractives, \% } \\
\text { ekstraktivi, \% }\end{array}$ & $2.02 \mathrm{t}$ & $2.12 \mathrm{t}$ & $5.60 \mathrm{t}$ & $1.50 \mathrm{a}$ & $6.23 \mathrm{a}$ & $7.65 \mathrm{t}$ & $5.1 \mathrm{t}$ \\
\hline \%1 NaOH, \% & 22.2 & 26.1 & 29.4 & 15.6 & 22.10 & 14.49 & 43.7 \\
\hline $\begin{array}{l}\text { Hot water, \% } \\
\text { vruća voda, \% }\end{array}$ & 7.15 & 8.07 & 8.40 & - & - & 2.19 & 14.6 \\
\hline $\begin{array}{l}\text { Cold water, \% } \\
\text { hladna voda, \% }\end{array}$ & 1.14 & 0.88 & 7.20 & 1.92 & 8.06 & 1.14 & 11.5 \\
\hline
\end{tabular}

$* \mathrm{t}$ - toluene-acetone-ethanol extraction, a - alcohol-benzene extraction / *t-ekstrakcija u toluen-acetonu i etanolu, a - ekstrakcija u alkoholbenzenu

were determined according to TAPPI T 494 om-01 and TAPPI T 403 om-91, respectively (Anonymous, 1998). In order to determine the effects of active alkali and $\mathrm{NaBH}_{4}$, the optimum cooking parameters were used.

Table 2 Pulping conditions of $R$. luteum and R. ponticum Tablica 2. Uvjeti dobivanja celuloze od biljaka $R$. luteum i R. ponticum

\begin{tabular}{|l|c|c|}
\hline $\begin{array}{l}\text { Pulping condition } \\
\text { Uvjeti proizvodnje celuloze }\end{array}$ & $\begin{array}{c}\text { Unit } \\
\text { Jedinica }\end{array}$ & $\begin{array}{c}\text { Value } \\
\text { Vrijednost }\end{array}$ \\
\hline Active alkali / aktivna lužina & $\%$ & $18,20,22$ \\
\hline Sulfidity / sulfidnost & $\%$ & 24 \\
\hline $\mathrm{NaBH}_{4}$ charge / udio $\mathrm{NaBH}_{4}$ & $\%$ & $0,0.3,0.5,0.7$ \\
\hline $\begin{array}{l}\text { Cooking temperature } \\
\text { temperatura kuhanja }\end{array}$ & ${ }^{\circ} \mathrm{C}$ & 160 \\
\hline $\begin{array}{l}\text { Time to maximum temperature } \\
\text { vrijeme postizanja najveće } \\
\text { temperature }\end{array}$ & $\min$ & 40 \\
\hline $\begin{array}{l}\text { Time at maximum temperature } \\
\text { vrijeme na najvećoj temperaturi }\end{array}$ & $\min$ & 90 \\
\hline $\begin{array}{l}\text { Liquor to raw material ratio } \\
\text { omjer otapala i sirovine }\end{array}$ & $1 / \mathrm{kg}$ & $4 / 1$ \\
\hline
\end{tabular}

\section{RESULTS AND DISCUSSION 3. REZULTATI I RASPRAVA}

The yield and chemical properties of $R$. luteum and $R$. ponticum pulps used in this study are presented in Table 3.

The screened yield and viscosity of $R$. ponticum was found lower than that of $R$. luteum by about $5.6 \%$ and $15.5 \%$, respectively. The kappa numbers of $R$. ponticum and $R$. luteum were determined as 49.24 and 45.74. According to these results, $R$. luteum is more suitable for pulping production than $R$. ponticum. The effects of $\mathrm{NaBH}_{4}$ on the properties of Rhododendron pulp are shown in Figure 1.

With the addition of $\mathrm{NaBH}_{4}$ to the cooking liquor, the yield and viscosity of the pulps increased and kappa numbers decreased. $\mathrm{NaBH}_{4}$ was effective on the screened yields as it had the ability to stop peeling reactions occurring in cellulose chains (Istek and Ozkan, 2008; Tutus and Cicekler, 2016). $\mathrm{NaBH}_{4}$ removes the lignin from the pulp i.e. selective lignin delignification occurs, while increasing the viscosity by preserving

Table 3 Screened yields, kappa numbers and viscosities of $R$. luteum and $R$. ponticum pulps

Tablica 3. Prinos prosijavanja, kappa brojevi i viskoznosti celuloze dobivene od biljaka $R$. luteum i $R$. ponticum

\begin{tabular}{|c|c|c|c|c|c|c|c|c|}
\hline \multirow{2}{*}{$\begin{array}{l}\text { Cooking No } \\
\text { Broj kuhanja }\end{array}$} & \multirow{2}{*}{$\begin{array}{l}\text { Active alkali, \% } \\
\text { Aktivna lužina, \% }\end{array}$} & \multirow{2}{*}{$\mathrm{NaBH}_{4}, \%$} & \multicolumn{2}{|c|}{$\begin{array}{c}\text { Screened yield, \% } \\
\text { Prinos prosijavanja, \% }\end{array}$} & \multicolumn{2}{|c|}{$\begin{array}{l}\text { Kappa No } \\
\text { Kappa broj }\end{array}$} & \multicolumn{2}{|c|}{$\begin{array}{l}\text { Viscosity, } \mathbf{c m}^{3} / \mathbf{g} \\
\text { Viskoznost, } \mathrm{cm}^{3} / \mathrm{g}\end{array}$} \\
\hline & & & R. luteum & R. ponticum & R. luteum & R. ponticum & R. luteum & R.ponticum \\
\hline 1 & 18 & 0 & 42.15 & 39.78 & 45.74 & 49.24 & 895 & 832 \\
\hline 2 & 20 & 0 & 41.78 & 38.50 & 42.16 & 46.78 & 860 & 800 \\
\hline 3 & 22 & 0 & 41.05 & 37.95 & 41.84 & 43.18 & 838 & 786 \\
\hline 4 & 18 & 0.3 & 43.03 & 41.50 & 42.06 & 46.56 & 928 & 870 \\
\hline 5 & 20 & 0.3 & 42.55 & 41.00 & 39.60 & 44.22 & 912 & 854 \\
\hline 6 & 22 & 0.3 & 41.83 & 40.03 & 37.78 & 42.76 & 886 & 808 \\
\hline 7 & 18 & 0.5 & 43.35 & 41.87 & 40.10 & 44.48 & 949 & 885 \\
\hline 8 & 20 & 0.5 & 42.91 & 41.21 & 38.88 & 41.98 & 924 & 868 \\
\hline 9 & 22 & 0.5 & 42.00 & 40.77 & 36.56 & 40.06 & 902 & 829 \\
\hline 10 & 18 & 0.7 & 43.78 & 42.18 & 38.98 & 42.02 & 988 & 902 \\
\hline 11 & 20 & 0.7 & 43.25 & 41.65 & 37.10 & 39.48 & 939 & 880 \\
\hline 12 & 22 & 0.7 & 42.60 & 41.23 & 34.24 & 37.98 & 918 & 840 \\
\hline
\end{tabular}



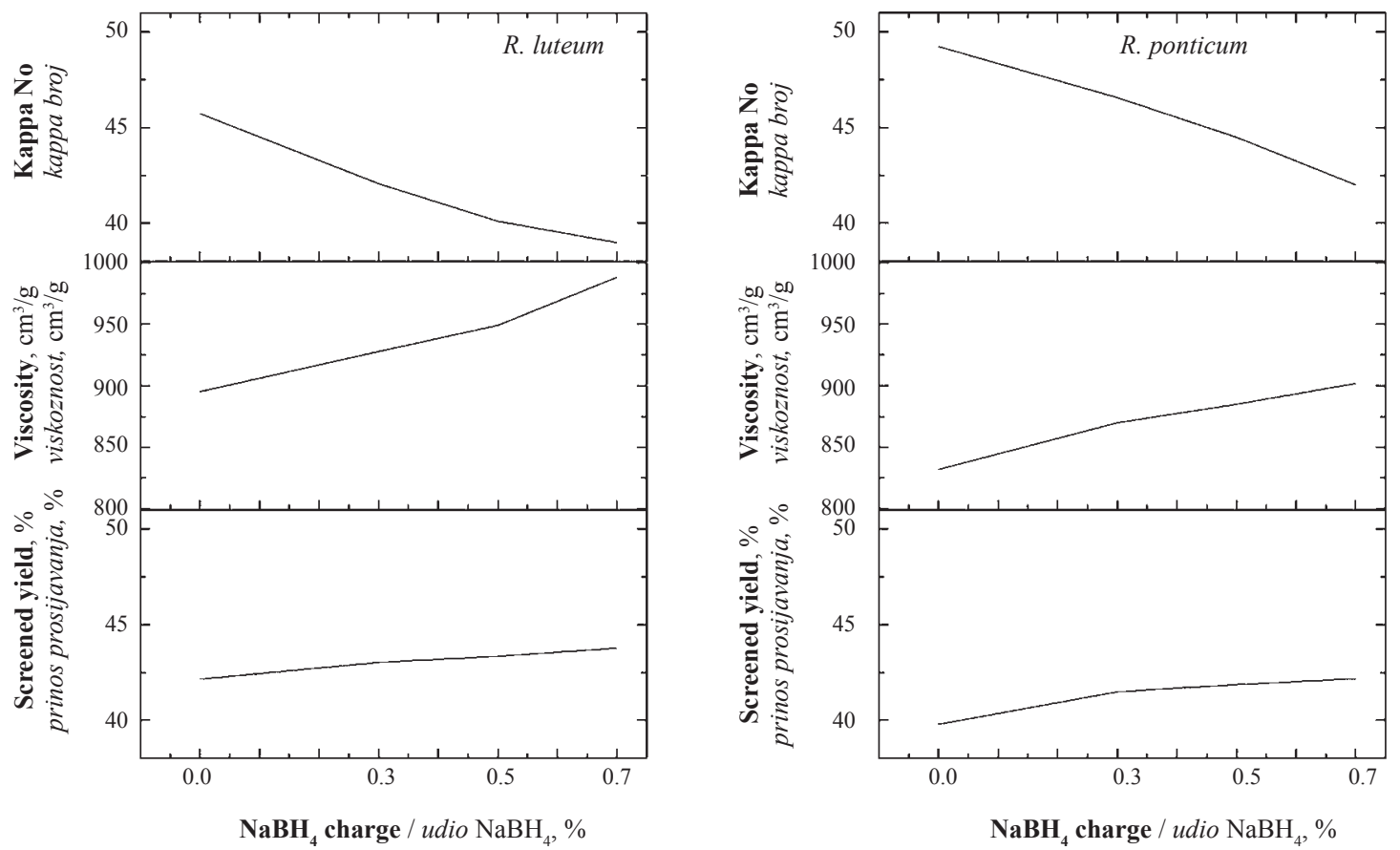

Figure 1 Effects of $\mathrm{NaBH}_{4}$ charge on yield, kappa number and viscosity of Rhododendron pulps Slika 1. Utjecaj udjela $\mathrm{NaBH}_{4}$ na prinos, kappa broj i viskoznost celuloze od rododendrona

carbohydrates (Tutus, 2008). It also prevents shortening of cellulose and hemicellulose chains as it prevents damage to carbohydrates. In this way, the viscosity of the pulps is increased and strength pulps can be obtained. Recent studies have shown a decrease in the kappa numbers of the pulps obtained with the addition of $\mathrm{NaBH}_{4}$ to the cooking experiments (Copur and Tozluoglu, 2008; Gulsoy and Eroglu, 2011; Istek and Gonteki, 2009). With the addition of $0.5 \% \mathrm{NaBH}_{4}$, the screened pulp yields of $R$. luteum and $R$. ponticum pulps increased by approximately $2.8 \%$ (from $42.15 \%$ to $43.35 \%$ ) and $5.3 \%$ (from $39.78 \%$ to $41.87 \%$ ), while kappa numbers decreased by $12.3 \%$ and $9.8 \%$, respectively. By keeping the active alkali high, the rate of depolymerization of carbohydrates during cooking increases. Therefore, both yield and viscosity decrease. The screened yields, kappa numbers and viscosity of $R$. luteum and $R$. ponticum pulps decreased by increasing the active alkali from $18 \%$ to $22 \%$. Many studies have reported that the increase of active alkali decreases the yield, kappa number and viscosity (Lopez et al., 2000; Yue et al., 2016; Zhai and Zhou, 2014).

The breaking lengths and burst indices of $R$. $l u$ teum and $R$. ponticum papers used in this study are given in Table 4.

According to Table 4, the breaking lengths and burst indices of the $R$. ponticum papers were found to be higher than those of $R$. luteum. It is clearly seen that the physical properties of the papers improve with the increase of active alkali and $\mathrm{NaBH}_{4}$ ratios (Figure 2).

Many studies have reported that boron compounds prevent peeling reaction during cooking, resulting in less damage to carbohydrates and therefore improved physical and optical properties of the papers

Table 4 Breaking lengths and burst indices of $R$. luteum and R. ponticum papers

Tablica 4. Duljina lomljenja i indeks pucanja papira proizvedenog od biljaka $R$. luteum i $R$. ponticum

\begin{tabular}{|c|c|c|c|c|c|c|}
\hline \multirow{2}{*}{$\begin{array}{l}\text { Cooking No } \\
\text { Broj kuhanja }\end{array}$} & \multirow{2}{*}{$\begin{array}{l}\text { Active alkali, \% } \\
\text { Aktivna lužina, \% }\end{array}$} & \multirow[t]{2}{*}{$\mathrm{NaBH}_{4}, \%$} & \multicolumn{2}{|c|}{$\begin{array}{l}\text { Breaking length, } \mathbf{k m} \\
\text { Duljina lomljenja, } \mathrm{km}\end{array}$} & \multicolumn{2}{|c|}{$\begin{array}{l}\text { Burst index, } \mathbf{k P a} \cdot \mathbf{m}^{2} \cdot \mathrm{g}^{-1} \\
\text { Indeks pucanja, } \mathrm{kPa} \cdot \mathrm{m}^{2} \cdot \mathrm{g}^{-1}\end{array}$} \\
\hline & & & R. luteum & R. ponticum & R. luteum & R. ponticum \\
\hline 1 & 18 & 0 & 2.21 & 2.88 & 1.90 & 2.10 \\
\hline 2 & 20 & 0 & 2.29 & 2.91 & 1.98 & 2.25 \\
\hline 3 & 22 & 0 & 2.32 & 3.02 & 2.06 & 2.31 \\
\hline 4 & 18 & 0.3 & 2.35 & 2.98 & 2.00 & 2.28 \\
\hline 5 & 20 & 0.3 & 2.40 & 3.05 & 2.15 & 2.45 \\
\hline 6 & 22 & 0.3 & 2.52 & 3.09 & 2.30 & 2.54 \\
\hline 7 & 18 & 0.5 & 2.57 & 3.07 & 2.17 & 2.43 \\
\hline 8 & 20 & 0.5 & 2.65 & 3.10 & 2.30 & 2.53 \\
\hline 9 & 22 & 0.5 & 2.79 & 3.19 & 2.45 & 2.62 \\
\hline 10 & 18 & 0.7 & 2.87 & 3.15 & 2.32 & 2.51 \\
\hline 11 & 20 & 0.7 & 3.01 & 3.32 & 2.54 & 2.68 \\
\hline 12 & 22 & 0.7 & 3.13 & 3.51 & 2.66 & 2.87 \\
\hline
\end{tabular}



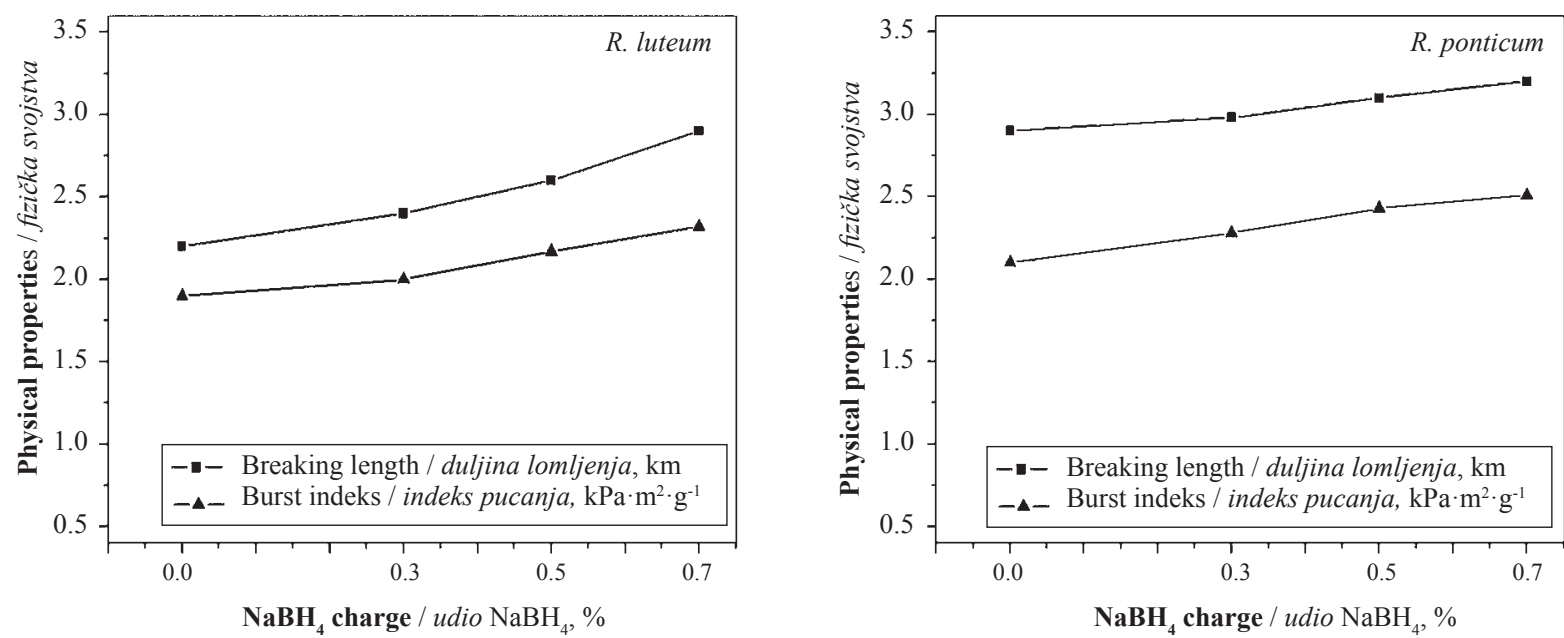

Figure 2 Effects of $\mathrm{NaBH} 4$ charge on breaking length and burst index of Rhododendron papers Slika 2. Utjecaj udjela NaBH4 na duljinu lomljenja i indeks pucanja papira od Rhododendrona

produced (Akgul et al., 2007; Copur and Tozluoglu, 2008; Istek and Ozkan, 2008; Istek and Gonteki, 2009; Gumuskaya et al., 2011; Erisir et al., 2015; Gulsoy et al., 2016). With the addition of $0.5 \% \mathrm{NaBH}_{4}$, the breaking lengths of $R$. luteum and $R$. ponticum pulps increased by approximately $16.1 \%$ and $6.4 \%$, and burst indices also increased by $14.2 \%$ and $15.7 \%$, respectively. According to data in Tables 3 and 4, optimum cooking conditions for the two species in $\mathrm{NaBH}_{4}$ added cooking experiments were determined by using $0.5 \% \mathrm{NaBH}_{4}$ and $18 \%$ active alkali (Cooking No: 7).

\section{CONCLUSIONS \\ 4. ZAKLJUČAK}

In this study, pulp and papers of $R$. luteum and $R$. ponticum species were produced by using Kraft-NaBH method and their properties were examined. As a result of this study, it was determined that the chemical properties of $R$. luteum and $R$. ponticum, such as yield, kappa and viscosity, were found to be better for pulp and paper industry. Besides, when the physical properties of the produced papers are examined, it is seen that they are suitable for the production of many paper types. The short-fiber pulps obtained from $R$. luteum and $R$. ponticum can be mixed with long-fiber pulps in certain proportions and evaluated for the production of many paper types. Since $70 \%$ of short-fiber raw materials are used for the production of writing-printing paper, the possibility of using $R$. luteum and $R$. ponticum species for the production of different types of quality paper is quite high.

\section{REFERENCES}

5. LITERATURA

1. Akgul, M.; Copur, Y.; Temiz, S., 2007: A comparison of kraft and kraft-sodium borohydrate brutia pine pulps. Building and Environment, 42 (7): 2586-2590. https:// doi.org/10.1016/j.buildenv.2006.07.022.

2. Akgul, M.; Camlibel, O., 2008: Manufacture of medium density fiberboard (MDF) panels from rhododendron $(R$. ponticum L.) biomass. Building and Environment, 43 (4): 438-443.

https://doi.org/10.1016/j.buildenv.2007.01.003.

3. Akgul, M.; Korkut, S.; Camlibel, O.; Candan, Z.; Akbulut, T., 2012: Wettability and surface roughness characteristics of medium density fiberboard panels from rhododendron (Rhododendron Ponticum) biomass. Maderas: Ciencia y tecnologia, 14 (2): 185-193. https://doi.org/10.4067/s0718-221x2012000200006.

4. Akgul, M.; Erdonmez, I.; Cicekler, M.; Tutus, A., 2018: The Investigations on pulp and paper production with modified kraft pulping method from canola (Brassica napus L.) stalks. Kastamonu University Journal of Forestry Faculty, 18 (3): 357-365. https://doi.org/10.17475/kastorman.499091.

5. Avci, M., 2004: Rhododendrons and their natural occurences in Turkey. Journal of Geography, 12: 13-29.

6. Ayrilmis, N.; Candan, Z.; Akbulut, T.; Balkiz, O. D., 2014: Effect of Sanding on Surface Properties of Medium Density Fiberboard. Drvna industrija, 61 (3): 175-181.

7. Birinci, E., 2008: Chemical Composition of Rhododendron luteum and Rhododendron ponticum Woods. VI. National Forest Faculties Student Congress, pp. 378-383, 8-9 May, Düzce-Turkey.

8. Comlekcioglu, N.; Tutus, A.; Cicekler, M.; Canak, A.; Zengin, G., 2016: Investigation of Isatis tinctoria and Isatis buschiana stalks as raw materials for pulp and paper production. Drvna industrija, 67 (3): 249-255. https://doi.org/10.5552/drind.2016.1542.

9. Courchene, C. E., 1998: The tired, the true and the newgetting more pulp from chips-modifications to the kraft process for increased yield. Proceeding of: Breaking the Pulp Yield Barrier Symposium, Tappi Press, Atlanta: 11-20.

10. Copur, Y.; Tozluoglu, A., 2008: A comparison of kraft, PS, kraft-AQ and kraft-NaBH4 pulps of Brutia pine. Bioresource Technology, 99 (5): 909-913. https://doi.org/10.1016/j.biortech.2007.04.015.

11. Daud, W. R. W.; Law, K. N., 2011: Oil palm fibers as papermaking material: Potentials and challenges. BioResources, 6 (1): 901-917.

12. Erisir, E.; Gumuskaya, E.; Kirci, H.; Misir, N., 2015: Alkaline sulphite pulping of Caucasian spruce (Picea orientalis L.) chips with additions of NaBH4 and ethanol. Drewno, 58 (194): 89-102. https://doi.org/10.12841/wood.1644-3985.067.07.

13. Gulsoy, S. K.; Eroglu, H., 2011: Influence of sodium borohydride on kraft pulping of European black pine as a 
digester additive. Industrial \& Engineering Chemistry Research, 50 (4): 2441-2444. https://doi.org/10.1021/ie101999p.

14. Gulsoy, S. K.; Oguz, S.; Uysal, S.; Simsir, S.; Tas, M., 2016: The Influence of Potassium Borohydride $\left(\mathrm{KBH}_{4}\right)$ On Kraft Pulp Properties of Maritime Pine. Journal of Bartın Faculty of Forestry, 18 (2): 103-106. https://doi.org/10.24011/barofd.267296.

15. Gumuskaya, E.; Erisir, E.; Kirci, H.; Misir, N., 2011: The effect of sodium borohydride on alkaline sulfite-anthraquinone pulping of pine (Pinus pinea) wood. Industrial \& Engineering Chemistry Research, 50 (13): 8340-8343. https://doi.org/10.1021/ie200633z.

16. Hafizoğlu, H.; Deniz, I., 2007: Wood Chemistry Lecture Notes. Karadeniz Technical University, Forest Faculty Publication, Trabzon, Turkey.

17. Istek, O.; Ozkan, I., 2008: Effect of sodium borohydride on Populus tremula L. Kraft Pulping. Turkish Journal of Agriculture and Forestry, 32 (2), 131-136.

18. Istek, A.; Gonteki, E., 2009: Utilization of sodium borohydride $(\mathrm{NaBH} 4)$ in kraft pulping process. Journal of Environmental Biology, 30 (6): 951-953.

19. Kaldor, A., 1992: Kenaf, an alternative fiber for the pulp and paper industries in developing and developed countries. Tappi Journal, pp. 141.

20. Kirci, H., 1987: Evaluation of Robinia Psedoacacia L. woods in the paper industry. Master Thesis, KTU Institute of Science and Technology, Trabzon.

21. Lopez, F.; Ariza, J.; Perez, I.; Jimenez, L., 2000: Comparative study of paper sheets from olive tree wood pulp obtained by soda, sulphide or kraft pulping. Bioresource Technology, 71: 83-86. https://doi.org/10.1016/s0960-8524(99)00044-9.

22. Oner, N.; Aslan, S., 2002: Technological properties and possible uses of trembling poplar (Populus tremula L.) wood. SDU Faculty of Forestry Journal, 1: 135-146.

23. Shrestha, R. M.; Budhathoki, N. P., 2012: The chemical compositions of Rhododendron arboreum, "Laligunras". Journal of Nepal Chemical Society, 30: 97-106. https://doi.org/10.3126/jncs.v30i0.9376.

24. Tank, T., 1978: Evaluation of Turkey beech and hornbeam species with NSSC Method. IU, Faculty of Forestry Publications No: 2326/231, Istanbul.

25. Tutus, A.; Eroglu, H., 2003: A practical solution to silica problem in straw pulping. APPITA Journal, 56 (2): 111-115.

26. Tutus, A.; Eroglu, H., 2004: An alternative solution to the silica problem in wheat strawpulping. APPITA Journal, 57 (3): 214-217.
27. Tutus, A.; Usta, M., 2004: Bleaching of chemithermomechanical pulp (CTMP) using environmentally friendly chemicals. Journal of Environmental Biology, 25 (2): 141-146.

28. Tutus, A., 2008: The effect of sodium borohydride on wheat straw pulp yield. II. National Boron Workshop, Proceedings Book, pp. 3003-3010, 17-18 April 2008, Ankara, Turkey.

29. Tutus, A.; Cicekler, M.; Karatas, B., 2011: Pulp and paper production by kraft-sodium borohydride method from poppy stems. II. International Non-Wood Forest Products Symposium, pp.183-190, 8-10 September, Isparta, Turkey.

30. Tutus, A.; Cicekler, M.; Deniz, I., 2012: Using of burnt red pine wood for pulp and paper production (Turkish, Abstract in English). KSU Journal of Engineering Science, Special Issue, 90-95.

31. Tutus, A.; Cicekler, M.; Ozdemir, A.; Altas, A., 2014: Evaluation of Astragalus membranaceus in pulp and paper production. III. International Non-Wood Forest Products Symposium (pp. 323-331), Kahramanmaras.

32. Tutus, A.; Cicekler, M., 2016: Evaluation of common wheat stubbles (Triticum aestivum L.) for pulp and paper production. Drvna industrija, 67 (3), 271-279. https://doi.org/10.5552/drind.2016.1603.

33. Yue, F.; Chen, K.; Fachuang, L., 2016: Low temperature soda-oxygen pulping of bagasse. Molecules, 21 (1): 85 97. https://doi.org/10.3390/molecules21010085.

34. Zhai, R.; Zhou, X., 2014: Enhanced effect of $\mathrm{NaOH} /$ Thiourea/Urea aqueous solution on paper strength of high yield pulp. BioResources, 9 (2): 2154-2166. https://doi.org/10.15376/biores.9.2.2154-2166.

35. ***Anonymous, 1998: Tappi Test Methods. Tappi Pres. Atlanta.

\section{Corresponding address:}

\section{EMRE BIRINCI}

Kastamonu University

Araç Rafet Vergili Vocational School

37800 Kastamonu, TURKEY

e-mail: ebirinci@kastamonu.edu.tr 